\title{
Dangerous Places According to the Ancient Egyptian Books of the Underwold during the New Kingdom
}

\section{Diana Azmy Youssef}

Department of Tourism Guidance, Faculty of Tourism and Hotels, Minia University

* Correspondence: dydyazmy@yahoo.com; Tel: +01222577149; Fax: +0862347762

\section{Article information \\ Received: 19 July 2020 \\ Revised: 3 October 2020 \\ Accepted: 11 October 2020 \\ Key words \\ Place of Destruction, \\ The damned, Lake of Fire, \\ Gates, Caverns.}

\begin{abstract}
It is clear that the ancient Egyptian culture is one of the most Near Eastern cultures, which concern with death. And this is obvious from the remains of the society which related in one way or another to death, and the dead. The ancient Egyptians were anxious about the dangerous places, which the deceased could confront during his journey through the Underworld. It seems that the ancient Egyptian was intercepted during his journey through the roads of the Underworld in some dangerous places; he may get harm, if he not knows certain spells that show him the right way to avoid the wandering and falling in it. These places appeared in the texts of Underworld Books.

This study aims to highlight the scenes of the dangerous places which the condemned deceased could confront during his journey in the Underworld, due to their evil doings. Such dangerous places, which depicted in the books of the afterlife, could be indicating that the penalty can be categorized in many types like: bounding, decapitation, reversal, burning and cooking, because they were deemed of eternal annihilation, and they are denied the reviving light of the sun god, who rejects them. Through these punishments they were denied any hope for eternal life.

This paper covered 14 scenes, and it could be investigated from these scenes of the dangerous places, which depict the punishment of the damned, that they distinguished by always depicting them in the lower registers, in contrast to the views of the sun's journey which occupied the upper registers. Such places which represent the hell in the ancient Egyptian conception, either by word or image. And despite the multiplying of the names which referring to the regions of hell, they may all be parts or places of the htmjt, those that represent hell. They are the most used words and depicted in various texts.
\end{abstract}

\section{Introduction}

Death and birth are the two events universally experienced, and it is their very commonality that helps to link cultures, regardless of any separation in time or place. For the Egyptians, as for other cultures, death was part of the journey of life; it considered a transition or transformation after which life continued in another form, in a spiritual form rather than the corporeal. ${ }^{1}$

The Egyptians occupy a unique position with regard to their approach to death and the possibility of resurrection, since so much of evidence that has survived comes from a funerary context. $^{2}$

As all human beings in every civilization; ancient Egyptians feared and hated death and wished to live a long life. They considered death the enemy of the good life on the earth. ${ }^{i}$ Nevertheless, death was considered a necessary condition for eternal life. "To live forever and ever" is the wish of the ancient Egyptians. Concerning death all sorts of terms of fear and fright are used. 4

The sun god Re and the dead make long voyages by boat along the Nile daily by the daily solar boat while passing through, the
Underworld nightly, in a nightly boat (symbolic of the coffin), and "land" in the other world. ${ }^{4}$

The nightly journey of the sun god was expressed most explicitly in the New Kingdom Royal Books of the Afterlife. During this journey, in order to emerge from twelve hours of night unscathed, he relied on protection from other entities. Although some of these were named deities, others play lesser parts in the pantheon ${ }^{5}$

There are certain spells, which were used to help the dead goes unscathed along dangerous places and their demoniacal guards. 4 In accordance with that, the so-called Book of the Dead contains the spells by means of which the dead man may hope to surmount the hindrances that he meets with in the course of his journey. Also it contains the names of the demons of the Underworld. This knowledge is considered most important to the dead man, since to the Egyptian the name was not a mere chance mark of the thing it belonged to, but an essential part of it. Gods and demons must perforce favor the man who knows and can pronounce their names. ${ }^{6}$

In order for the sun god to rise again and resurrect all the good spirits, he must overcome or resist the enemies of the sun god to repel and control the evil of Apophis to not hinder the sun god's night journey. Gods, creatures, and spirits all join hands in 
confronting the evil of Apophis; controlling him by using magic or by immobilizing him so that the sun god can continue his journey, throughout the underworld. In addition, the gods cooperate in the punishment of the guilty and cursed enemies of the gods, in places of punishment and destruction that spread throughout the Underworld. ${ }^{7}$

Though Apophis is the ultimate enemy of Re who is considered the negative image of order, primarily cosmic and then, since earthly order cosmic order. The embodiment of evil in that sense, which implies that he is forever late mythical records, ii and Seth is known to be the opponent of Osiris; the sinners were regarded to be common enemies of both great gods. In the texts they alternated the titles: "enemies of $\mathrm{Re}^{\mathrm{N}}$ and "enemies of Osiris. The enemies of the gods were sentenced to have a second death through the destruction of their souls. ${ }^{4}$

Those who were denied the heaven of Osiris and immorality were considered the enemies of Maat who represented righteous, justice and marinated the balance of the universe; those were the damned. ${ }^{9}$

They were exposed to punishment and torture in different ways described by the texts and scenes from the various religious contexts. iii They put on a slaughtering-block and killed like a piece of cattle. As a punishment he is put into a burning division of hell. He may fall into pools, which are actually full of serpents with firing flames as they (serpents) are responsible for the punishment by burning in the caldrons or copper basins. ${ }^{11}$

\section{1-Place of Destruction (ḥtmjt):}

This word is derived from the stem hitm, iv to destroy, to perish. It was one of the most used words, which give the meaning of destroying the sinner and removing his being. There are two destinies waiting for the deceased that beside the conception of a kingdom of heaven also there is a dark subterranean realm of the dead as a place of punishment was present, as the Underworld Books depicted it, a total destruction for the sinners. ${ }^{13}$

\section{- Place of Destruction according to Amduat:}

In the closing text of the First Hour, there is a dialogue of the sun god with the gods of the netherworld. It indicates that, those who are in "hell", catch sight of the sun. ${ }^{14}$

shdw n.k kkwt

Illuminated for you is the darkened

Srq.k hitmjt

that you let breath the place of destruction

It seems that the great god enters in the pre-eternal darkness that he passes through a cave, which its entrance and its back are in darkness. The gods, 3 h spirits and deceased couldn't approach from this cave; only the great god can pass through it. So may be the word srq could came suitable in the text, that the great god cause the increasing of the glow of the hell, to punish his enemies. $^{14}$

The text of the lower register of the Third Hour indicates what the deities of this hour have to do to the souls, who are in the place of destruction. ${ }^{15}$

It seems that god Re put these gods as guardians in the place of destruction for this mission to the enemies of Re. And it is obvious from the text, that they also live on devouring these condemned enemies. ${ }^{16}$
Also in the closing text of the Third Hour, the sun god addressing Osiris and his followers, and promise them that they will not fall in the place of destruction. ${ }^{16}$

\section{- Place of Destruction according to the Book of Gates:}

At the lower register of the Fifth Hour, there are twelve gods carrying the serpent of time, adorned with hieroglyphs for "life time". These gods brought the enemies to the place of destruction. That there are many gods and demons, who not just punish these enemies, but also they guard them as prisoners in this area and assign them to the place of destruction, that they could not ever come out from this place. ${ }^{17}$

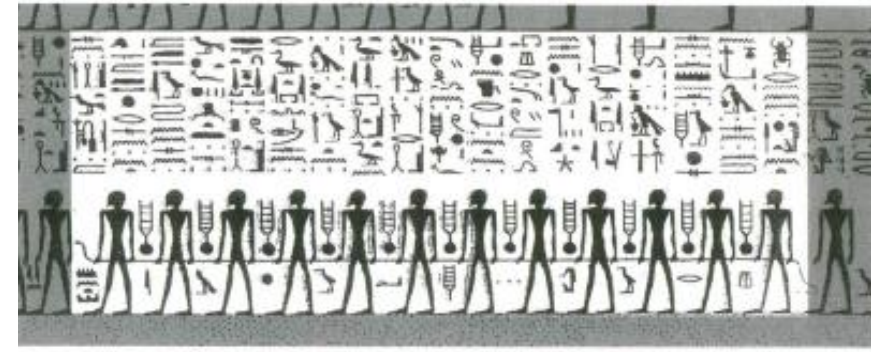

Fig. 1, twelve gods carrying the serpent of time, (after, Hornung (2013), The Egyptian Book of Gates, p. 164).

\section{- Place of Destruction according to The Book of Caverns:}

The Book of caverns has described this place in extensive way, with many punishments which committed on the guilty deceased and enemies, while there is no depiction of this place at all. This place remained invisible, hidden and deep. As indicating in the last cavern in the Sixth Division, the Sun God speaks to his enemies, describing it as a Place of Destruction which has no escape.

sjp. i th $\mathrm{n}$ htmjt $\mathrm{n}$ prt m.s "I deliver you to the Place of Destruction, which has no escape". ${ }^{18}$

So may be this place is located out of the Netherworld. And this is the reason which make this area is depicted as a two arms, emerging from invisible depth. $v$ Like in the third register of the Fifth Division, there are two arms from the earth support a crescent-shaped caldron containing four heads and four hearts. 17 Between the arms supporting the caldron are three columns of enigmatic writing: ${ }^{\mathrm{c}} \mathrm{wj} \mathrm{m}$ htmjt .... (?) imj d3t "The two arms in the place of perdition.... which is in the Netherworld" 20

Also the two arms of htmjt found in the fifth register the same Fifth Division. The two arms emerging from the earth lift up a crescent-shaped caldron which contains four reversed shadows, four soul-birds and three "signs of flesh". viwnn htmjt $\underline{h r}$ b3w h 3 wt šwwt nt hftjw $\mathrm{R}^{\mathrm{c}}$ Wsir "The destructress who holds the souls, the bodies, the shadows of the enemies of $\operatorname{Re}$ and Osiris" 22

\section{-Place of Destruction according to The Book of Eath:}

At the lower register of part A, the first scene from the left, represents a mixed group of minor chthonic deities. 


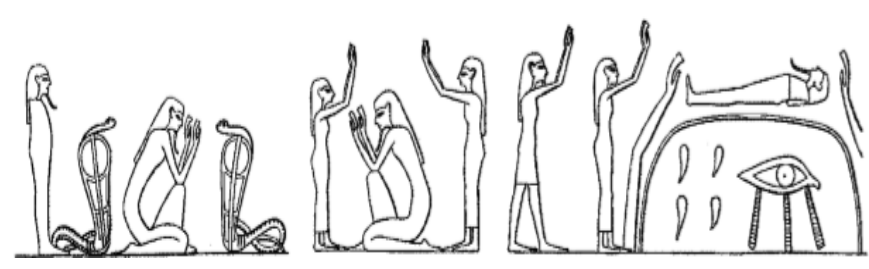

Fig. 2, mixed group of minor chthonic deities.

(after, Roberson (2007), The Book of Earth, fig. 14).

Over this scene the solar barque passes, prior to entering the body of Aker.

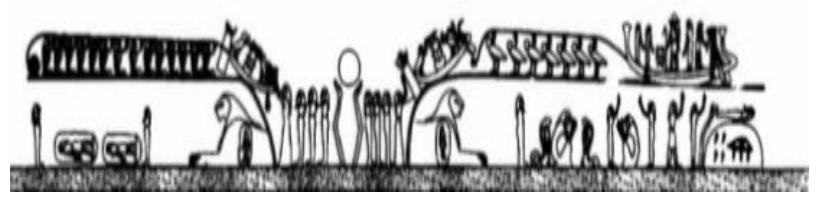

Fig. 3, lower register part A.

(Hornung (1999), The Anciet Egyptian Books of the

Afterlife, fig. 55).

The arms of Geb ( ${ }^{\mathrm{c}}$.wj Gb) embrace a mummy called the Mourned One atop a mound containing a weeping eye and four hieroglyphs designating flesh; the indicated mourning is continued by other figures at the left. As at the end of the Amduat, the regeneration of $\mathrm{Re}$ is set in contrast to the mourning for Osiris. ${ }^{23}$

The annotation from the tomb of Ramesses VI identifies the locale as the Place of Destruction and also mentions the primordial gods Nun and Tatenen. ${ }^{24}$

Also in the lower register of part D, there is a giant, female mummy "The corpse of She-who-annihilates" lies within a semi-ovoid sarcophagus with a clearly defined foot end. ${ }^{25}$

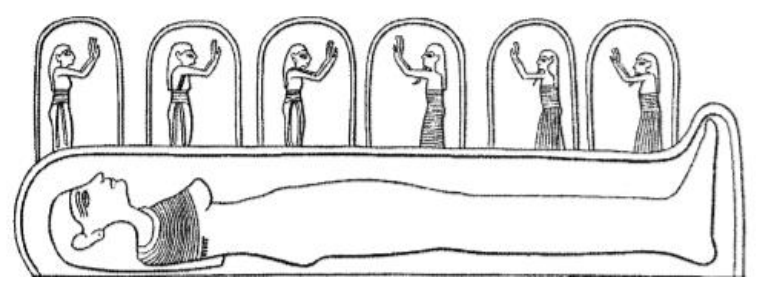

Fig. 4, a giant female mummy lies in a semi-ovoid sarcophagus.

(after, Roberson (2007), The Book of Earth, fig. 68).

Six smaller oval shapes enclose praising figures above the giant sarcophagus, which obscures the bases of the smaller structures and the feet of the individual figures within them. Three praising men stand in the ovals to the right; three praising women stand in the ovals to the left. The two groups face one another. The same three names- "Mystery" (št3.t), Senyt (sny.t), and "Face Destroyer" (ḥtm har)- appear over both male and female figures. ${ }^{24}$
Hornung suggests that the figure may represent the personification of the "Place of Annihilation", where the Damned are punished. ${ }^{17}$

\section{2-The Land of Sokar:}

In the Fourth Hour, through Re's journey in the Netherworld, here lay the desert of Rosetau, "the land of Sokar, who is on his sand". Sokar has dominion in this land. Dreary is the waste of sand, limitless the desert, gloomy and somber the landscape. No blade of grass is seen, no tree, no herbage; naught grows, naught lives. ${ }^{23}$

\section{-The Land of Sokar according to Amduat:}

Here in the Fourth Hour, Sokar land described many times as ${ }_{26}$ unapproachable path or land. It is also called Rosetau or Imhet.

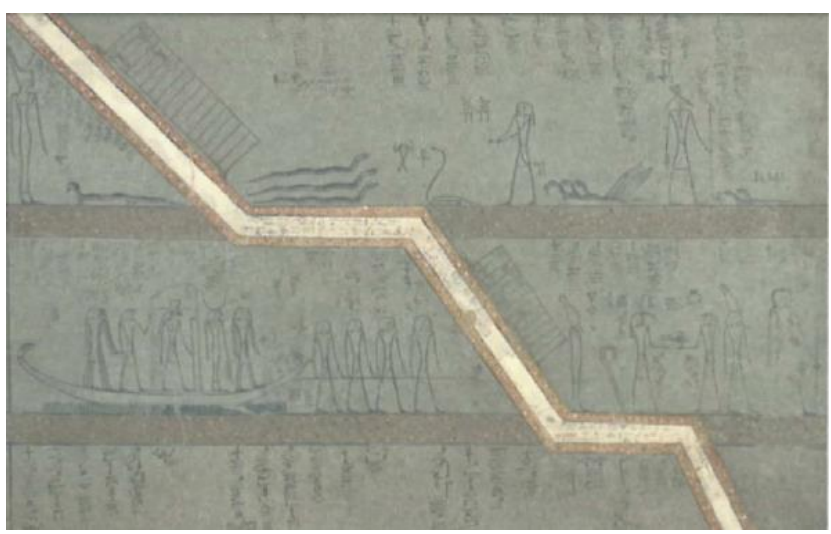

Fig. 5, the whole hour is traversed by a zigzag path repeatedly closed by doors cutting the way and therefore called 'Knives'.

(after, Hornung\&Abt (2009), The Egyptian Amduat,

$$
\text { p. 116). }
$$

In the upper register, there is a serpent with three-headed and provided with wings and legs, which lives in the path of Rosetau:

m r3 mtn pn dsr nj r 3 -st 3 w

at the edge of this unapproachable path of Rosetau

Also in the lower register the text talk about five deities and describe this land as the secret way of Imhet: vii

' $h$ '.sn $\mathrm{m}$ t3 $\mathrm{r}$ w3t th št $3 \mathrm{t}$ nt jmḥt

They stand in the earth at this secret way of the Imhet

The word Imnt ${ }^{12}$ is usually referred to the kingdom of dead, as a preferred place for the dead people, and the word Imht which mentioned in this text, almost has the same meaning, as an Underworld, kingdom of dead or necropolis. 12 And there are many texts, which mention it as a place for a righteous people, and forbidden for the sinners.

As it was mentioned above, that this path is a sandy way. It could hinder the trip of the sun barque. It needs to be towed to continue its progress. So it could be one of fears for the deceased, that the water would be barren or dried up. The text in the upper register of the Fifth Hour assures this concept. There are four gods standing in a place, which seems to has no water in it, and the great god Re speaks to them, hoping that the water not to dry up, and their river banks be high. ${ }^{14}$ 


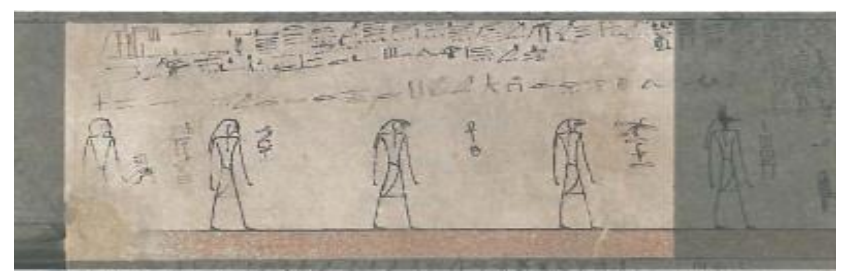

Fig. 6, four gods standing in a place which seems to

has no water.

(after, Hornung (2009), The Egyptian Amduat, p. 146).

In the Seventh Hour, the great god passes along in a place, which called "the path of the cavern of Osiris", which has the same descriptions of the land of sokar. He was elevated by the magic of Isis, to turn away from Apophis. viii It has a sandy nature like the Soker land. The text of this hour describing Apophis lying on his sandbank after swallowing up the waterway of the sun barque. 15 This path also described as a mysterious path, that the great god needs the help of certain gods and goddesses to guide and protect him. ${ }^{15}$

\section{3-Lakes of the Underworld:}

Generally, the symbolism of lakes as an important part from the topography of the Underworld in ancient Egypt came from the symbolism of water in ancient Egypt. Water is linked with the function of Osiris as the central figure of Egyptian funerary belief by the virtue of his dying and reviving as well position as judge and ruler of the Underworld. These aspects of Osiris are dealt with in detail by Plutarch in his treatise on Isis and Osiris of the early second century A.D., in which he described how the Ancient Egyptians equated Osiris with River Nile ix and the Nile god Hapy. ${ }^{30}$

\section{-The Lake of Criminals:}

In the Book of the Two Ways the Lake of Criminals š hbntjw is a place of passage, and the deceased wished not to fall a victim to its guardian, who cuts and kills those who sail over it. It occurs in Coffin Texts spell 1099 as a place where the deceased is frightened that his head can be chopped off on the slaughter block of Whose-Face-is-behind, the Sharp One. $\mathrm{x}$

The Lake of Criminals shares with the Lake of Fire the aspects of being a place of torture for the sinners. It is also a place where the deceased is pictured as a bull and is taken to the slaughter block to be sacrificed but also a place that every deceased should sail over in his way to the underworld. ${ }^{32}$

\section{The Lake of Primeval Water Nun:}

To some extent, one from those lakes also is $\breve{s} / \mathbf{s} w-N w n, x i$ "the Lake of Primeval Water Nun". It is located on the west bank of the underworld, where the serpent Rrk is punished by wrecking him under the lakes' water Nun:

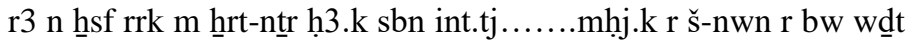
it.k irt šct.k im
"Spell to face the serpent Rrk in the Kingdom of the Dead hrtntr; go back; fail as a bounded creature; wreck through the water of Nun at the place where your father ordered to slaughter you". 34

\section{The Lake of hbt:}

The "Lake of hbt" where the ear of grain are grown and the real care of ntrw imjw š-hbt, 'the spirits of the dead', that took a rectangular form. While sometimes it is appeared as a rounded pit or cave with red wavy lines look like fires. Inside it, the wavy cobra is dwelled and mentioned without name. It is surrounded with two protector gods guarding the lake, called nbj 'who Burns' and stj 'who Strikes with Firing Flames'. ${ }^{35}$ Serpents along the mountains, Lake of Fire and Lake of Knives are seen as good spirits who represented as a guardians equipped with both fire and knives. They spit their flames against damned, chop off the heads of the unprepared dead, and shoot their knives against the passers. ${ }^{36}$

\section{Lake of Fire, Lake of Knives:}

The Lake of Fire is depicted on the floor of some Middle Kingdom coffins from el-Bersha in what is known as the Book of the Two Ways. In this book, the Lake of Fire is represented as a stretch of water that is painted in red. ${ }^{36}$

The Lake of Fire is found also in the Book of the Dead Chapter 126. The vignettes of this chapter show four baboons sitting at the four corners of the Lake of Fire with four nsrt signs on its four sides. The four baboons sitting at the bow of the barque of the sun god Re are connected with the sunrise. They act as judges in the divine tribunal and decide who may gain access to the sacred portals of the west, or who shall be thrown to the monster that guards the interior of the Lake of Fire. ${ }^{36}$

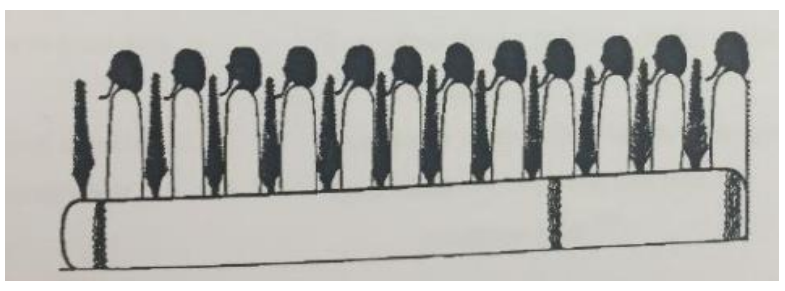

Fig. 9, the Lake of Fire at the upper register of the

Third Hour in the Book of the Gates.

(after, Hornung (1979/1980), Das Buch von den Pforten II, 80).

In the lower register of the sixth division of the Book of Gates, there is a picture of a circular, fiery pool described as a "holy pool". It is represented as a cavity full of fire. Inside this cavity, a uraeus is depicted. This cavity of fire is described as another variant of the Lake of Fire.

\section{The Lake of Cobras:}

In the upper register of the Fourth Hour in the Book of the Gates, there is the š-icrwt, 'the Lake of Cobras', the Lake of Fire took a different depiction. There is a rectangular lake and ten Uraeus-serpents surrounding it. Uraeus Serpents were firespitting cobras who represented the sun god as well as the heat of the sun. Their presence here implies this lake is a Lake of 
Fire where the wicked ones (who are against Re) were burned, xii as indicated in the text addressed by Re to them. xiii

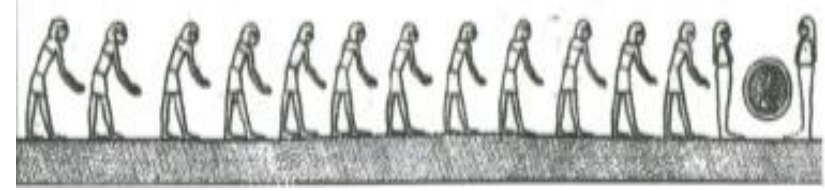

Fig. 10, the fire cavity, Six Hour of the Book of the Gates.

(after, Hornung\&Abt (2013), The Egyptian Book of Gates, p. 216).

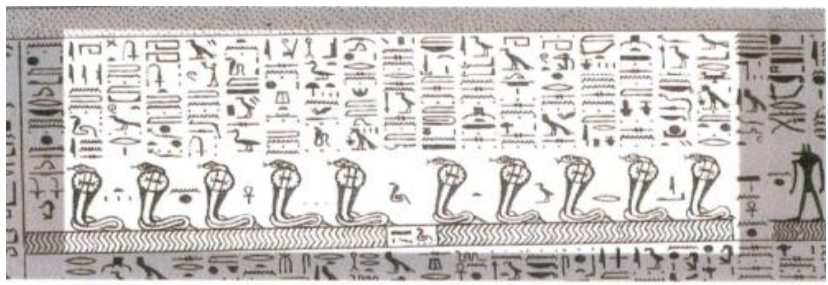

Fig. 11, rectangular lake and ten uraeus-serpents surrounding it, Fourth Hour of the book of the Gates. (after, Hornung\&Abt (2013), The Egyptian Book of Gates, p. 102).

\section{Region of Penshetay:}

In the middle register of part A from The Book of Earth, a large, funnel-shaped area bisects the body of the protective serpent Mehen, the "Enveloper" or "Coiled One".

ntr pn m shr pn hifзw ${ }^{c_{3}}$ Mḥn

"This god in this form: the great serpent, Enveloper". 24

The serpent's body assumes the form of two great mounds with a central depression between them, recalling the form of the horizon. 23 Within the V-shaped area at the midpoint of Mehen's body stands a large, ithyphallic deity, identified in the version of Ramesses IX as "He Who Hides the Hours" (jmn wn.wt). Beneath the phallus of the central deity sits a small figure in the shape of the "child", atop the sign for "flame". 24 Beneath the flame hieroglyph stands a man with upraised arms, identified as the "Bloody One" (snyf), xiv who receives a tendril of flame, which issues from the phallus of the central deity. 24

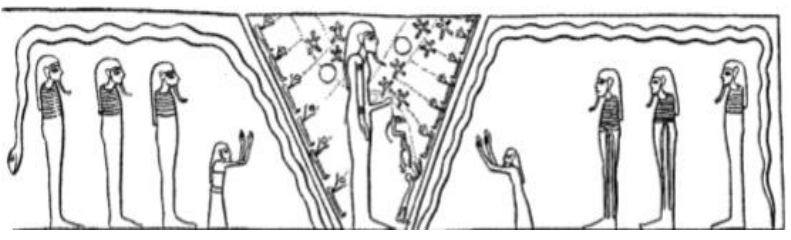

Fig. 12, the birth of the hours. (after, Roberson (2007), The Book of Earth, fig.11).
In all versions prior to Ramesses IX, the present tableau was placed beneath a scene, which depicts the procession of the solar barque as it is dragged above the body of Mehen and the funnel-shaped pit. ${ }^{24}$

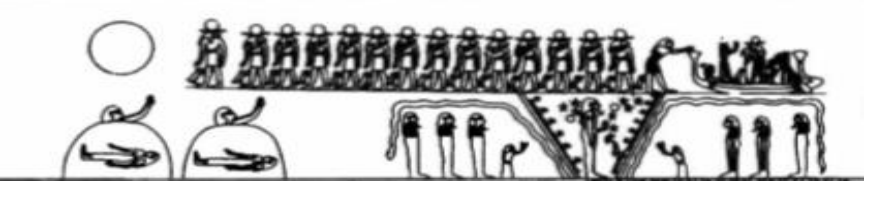

Fig. 13, the procession of the solar barque above the body of Mehen.

(Hornung (1999), The Ancient Egyptian Books of the Afterlife, fig. 55).

A name Penshetay, $x v$ apparently refers to the funnel shaped depression at the center of the scene, in the version of Ramesses IX. 24 The primary function of this locale seems to entail the production of the divine fire, xvi which fills the $\mathrm{v}$-shaped depression. It is this region of Penshetay "which gives to the mysterious corpses", who in turn, transform into children. The children presumably refer to the "hours" (wn.wt), represented as discs held in the goddesses' hands and stars above the head of the central figure, "He-Who-Hides-the- Hours" (jmn wn-wt). 24 In addition to this procreative process, Penshetay also serves as a location for the incineration of the Damned. 43 The potentially dangerous nature of the Penshetay region is indicated by the presence of the great serpent, Mehen, whose protective coils completely isolate to two groups of attendant deities from either side of the fiery pit. xvii The pit itself is also covered, in order that the procession of the solar barque might moor safely above it, while in the lower register of part A, the solar barque plunges directly into the unknown depths, and out of sight. 24

\section{5-Gates:}

In the hereafter the dead has to pass several gates in order to reach the ultimate object. They are a hindrance, which he has to overcome. He may be stopped at the gate. Usually the gatekeepers are demonical beings, who wish to hurt or kill him, when he approaches them. Only forced by a powerful charm they will let him pass and the doors will open. Sometimes it is said that the gates lets only just people through, but keeps sinners at bay. The texts that deal with the gates, give the necessary knowledge to somebody for being admitted and reaching one's destiny: to be with $\mathrm{Re}$ in the heavens or in the realm of Osiris, 4 when the dead sets off through the netherworld to Osiris "the gates of the roads of Imh.t" are opened to him. 32

\section{The Gate of Sais (forbidden Gate of Sais) according to Amduat:}

The Eleventh Hour is filled with preparations for the coming sunrise, the sun's emergence from the eastern mountain of the sky. In the form of serpents, Isis and Nephthys transport the crowns of the two lands to the eastern gate of Sais, where four forms of the goddess Neith are standing. 23 


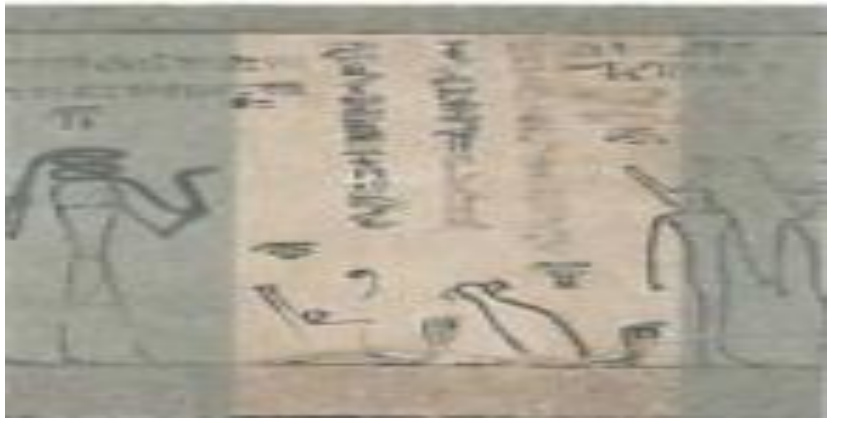

Fig.14, two cobras transport the crowns of the two lands to the eastern gate of Sais.

(after, Hornung\&Abt (2007), The Egyptian Amduat,

$$
\text { p. 342). }
$$

At the end of the upper register, next to the retinue of the sungod, four additional goddesses sit on double serpent, each holding a hand in front of her face, 16 from them emanates the fiery breath that incinerates the enemies who are cast into flame-filled pits in the lower register. The serpent 'Who burns millions, along with avenging goddesses holding knives, carry out this last judgment, averting any threat to the rising of the sun. Horus, who is watching over the scene, condemns the enemies the enemies of his father. 23

The text in the middle register of the Eleventh Hour, describe the gate of Sais as a mysterious, forbidden and unapproachable gate: xviii ntsn Z33w sb3 dsr Z3y

They are those who guard the forbidden gate of Sais jwty rh.f n m33 n ptr Which is unknown, unseen and unperceived.

\section{The Gates according to the Book of Gates:}

It seems that when $\operatorname{Re}$ has passed through, and the gate is closed, the gods outside set up a wail, for they must abide in darkness until he re-appears. xix The manner which makes them feel with horror, as indicated in the text of the lower register in the First Hour: $x x$

hwt hr jmyw Zmjt.sn

Then those who are in their desert wail

sdm.sn h33 3 pn

when they heir this gate being closed.

And at the end of the Second Hour, the gods wail when Re passed through as indicated previously: 49

htmjn ${ }^{\circ} 3$ pn

Then this door is closed

hwthr jmyw sbht.sn

Then those in their gate wail

The two guardians in the Second Hour have menacing titles: 42

'mw-jwtyw q' h.f 'wy.f(j) n r'w

who devoures the non-existing, he bends his arm for $\mathrm{Re}$

shbw-znfw q⿳⺈(.f) ${ }^{\circ} w y . f(i) n r^{\circ} w$

who slurps blood, he bends his arm for Re

And the text describes the serpent upon the doorway of the Fifth

Gate: 49

sty $m$ jrt.f

Who burns with his eye

\section{The Cavernes of the Underworld:}

These caverns of the Underworld were inhabited by a fantastic array of beings. They are shown with human bodies, but the heads of animals, birds, reptiles or insects. Some have two heads, or a head that faces backwards. Others have threatening objects, such as knife or a torch, in place of head. They are given alarming or grotesque names like 'Blood-drinker who comes from the Slaughter house', 'Backward-Facing One who comes from the Abyss' or 'One who eats the excrement of his hindquarters'. These beings are usually referred to a demon. They might be dangerous to humanity, but they were under the command of the high gods. xxi

\section{The Caverns according to the Amduat:}

One of those caves called tp ht Wsir which represents the cave of Osiris where the sun god stops everyday paralleling to the Seventh hour of the Amduat. This cave is mentioned as unwater place, cause of the serpent Apophis drank all its water in order to give out the daily cycle of the boat while by the powers of magic facilitates his way (the way of $\mathrm{Re}$ ):

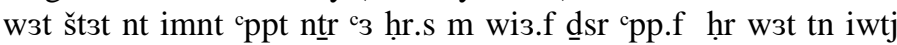
mw.s iwty stâs.s sqdd.f $\mathrm{m}$ ḥk $3 w$

"The mysterious way of the west where the sun god passing by his secret boat; he crosses his way without water; without winds; xxii but he successfully sails with magical powers". 14 The upper and lower Registers of the Eighth Hour at the book of Amduat are divided into five 'caverns' or 'vaults', closed by wooden doors (painted red) that open the invocation of the sungod passing between them. The doors are called knives. xxiii The texts also describe how the ba-souls of the gods and the dead joyfully respond to the sungod from these crypts or vaults, which stand for all the crypts in the netherworld. Though the sound of this rejoicing is intelligible speech to the god, human ears hear it only as the cries of animals or other sounds in nature, such as banging on metal or splashing water: such is the distortion even of sound in the afterlife! 23

\section{The Caverns according to the Book of Gates:}

While about what is well known as hasst "Firing Caves", are found at the sixth hour of the Book of Gates. It is similar to the Firing Shift: it is mentioned that, the place especial for Osiris, where both of the earthly gods and the souls couldn't reach because of the firing flames of the cobra serpent:

wnn.sn m dbnw n hisst th wnn icrt ${ }^{\mathrm{c}} \mathrm{nh}$ t $\mathrm{m}$ h 3 st tn wnn mw n hisst $\mathrm{m}$ sdt iwtj hзj ntrw t3 b3w t3 $\mathrm{r}$ hasst tn $\mathrm{m}^{-\mathrm{c}}$ nsrt $\mathrm{n}$ icrt th srq ntr pn

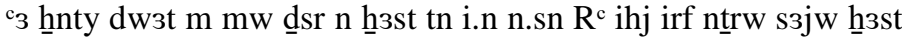
dsrt ddt mw (n) hnty-igrt iw mw n hasst $\mathrm{n}$ Wsir ....... nsrt hh.tn nsbw.tn $\mathrm{r}$ b3w ${ }^{\mathrm{c}} \mathrm{r}$.sn $\mathrm{r}$ thj Wsir.

"Here, in the Firing Cave where the Cobra Serpent are found; the water of this cave is from fire; in order to prevent both of the earthly spirits and gods to be near from it; also because of the firing flames of the cobra; While this great god the noble of the underworld breaths from the divine water of this firing cave. Re says to the gods of the firing cave: welcome the great guardian gods of the separated guardian gods; this cave gives water to the noble of underworld 'igrt'; Your firing water of the cave of Osiris; the flames of your breathes against the spirits who try to reach to Osiris". 49

\section{Conclusion}


Ancient Egyptians were from the first people who were concern about death and what will happen after it. And all their great culture is depended on their concern about their destiny after death, their well decorated tombs which remain until now, indicate that they hoped to spend a blessed eternal life with their gods. But at the same time, it seems that there will be many fears which they could confront during their journey in the Underworld, and they have to overcome them to guarantee a good eternal life, being on the way of Re.

Ancient Egyptians feared and hated death and wished to live a long life. They considered death the enemy of the good life on the earth, which he loved and knew how to enjoy with a gay meal accompanied by play and dance. Nevertheless, death was considered a necessary condition for eternal life. "To live forever and ever" is the wish of the ancient Egyptians. Concerning death all sorts of terms of fear and fright are used.

It seems that the ancient Egyptian was intercepted during his journey through the roads of the Underworld in some dangerous places; he may get harm. And it is important that the dead on his nightly journey knows how to "pass" dangerous places safely as the dead goes unscathed along dangerous places and sails to heaven. There are many places in the realm of the dead where the dead has a great deal to suffer. Some of them are divisions of hell like the Place of Destruction, where he may be tortured or burnt. He goes along roads of which he must know the right direction. Along these roads pools of fire wait him, which are usually full of flames. Certain spells help the dead to pass these dangerous places and their demoniacal guards and to avoid the wandering and falling in it. These places appeared in the texts of the Pyramid Texts, Coffin Texts, Amduat and Book of Gates.

So the journey of the deceased's boat from the north to the south of the sky is envisaged as the daily journey of the sun god Ra from the east to the west. In accordance with that, the so-called Book of the Dead contains the spells by means of which the dead man may hope to surmount the hindrances that he meets with in the course of his journeying. Above all, it contains the names of the demons of the Underworld as well as the names of objects there. This knowledge being most important to the dead man, since to the Egyptian the name was not a mere chance mark of the thing it belonged to, but an essential part of it. Gods and demons must perforce favor the man who knows and can pronounce their names.

The regions that represent hell in ancient Egyptian thought were represented in the picture and the word and in more detail in the books of the afterlife, especially the Book of Caverns, Book of Earth and Book of Gates. However, there are many words, which refer to the hell like istw, nmt, hasdw, but they may all be parts or places of htmjt rejoin, the one that represent the hell. It is the most frequently used word depicted in various texts.

The Place of Destruction was one of the most used words, which give the meaning of destroying the sinner and removing his being. There are two destinies waiting for the deceased that beside the conception of a kingdom of heaven also there is a dark subterranean realm of the dead as a place of punishment was present, whereas the Underworld Books depicted it as a total destruction for the sinners. It has many places, which are like cauldrons filled with fires.

Also among the dangerous places are the lakes of the Underworld, like the Lake of Fire. The Lake of Fire threatens to cut out all that is impure in the soul. So if a person enters it, he could be identified with those aspects, that are unregenerate and unable to transmit the life-giving light of Re, then they will suffer a torment similar to being hacked to pieces. Such a fate is vividly depicted in Eleventh Division of the Book of What Is in the Underworld where the "enemies of Osiris" are shown both being cut up with knives and burnt.

While Lake of Cobras' is considered as the Lake of Fire, that took a different depiction. There is a rectangular lake and ten Uraeus-serpents surrounding it. Uraeus serpents were firespitting cobras, who represented the sungod as well as the heat of the sun. Their presence here implies this lake is a Lake of Fire where the wicked ones (who are against Re) were burned.

Benben-house is considered as one of the punishment places for the condemned ones in the Underworld, that they were burnt in it. Penshetay also serves as a location for the incineration of the Damned.

In the hereafter the dead has to pass several gates in order to reach the ultimate object. They are a hindrance, which he has to overcome. He may be stopped at the gate. Usually the gatekeepers are demonical beings, who wish to hurt or kill him, when he approaches them. Only forced by a powerful charm they will let him pass and the doors will open. Sometimes it is said that the gates lets only just people through, but keeps sinners at bay.

Also along the journey of the deceased, the Underworld has many caverns, which are inhabited by a fantastic array of beings. They are shown with human bodies, but the heads of animals, birds, reptiles or insects. Some have two heads, or a head that faces backwards. Others have threatening objects, such as knife or a torch, in place of head. They might be dangerous to humanity, but they were under the command of the high gods

All these dangerous places were dedicated to punish the condemned ones. The damned and the sinners are considered as enemies to gods and to the sungod, that they did not do their will. So after the death of the damned ones, they arrived to the Underworld, and the sungod with his accompanied deities and other creatures, punish them as penalty for their evil doings during their life on earth.

They represent the enemies of god Re, god Osiris, the righteous ones and the other gods. So they were usually took two titles: hftyw Wsir, hftyw $\mathrm{R}^{\mathrm{c}}$, while the other title is mwt, which means the sinners. They represent the enemies of nightly journey, who did not do the will of gods on earth.

There are many places in the realm of the dead where the dead has a great deal to suffer. He is put on a slaughtering-block and killed like a piece of cattle. He may fall into pools, which are usually full of flames. As a punishment he is put into a burning division of hell. The netherworld is full of sinister caves. There are places of judgment where he is slaughtered or completely destructed. To the punishment by burning the possibility belongs of putting the dead into cauldrons or copper basins. Under them a fire is burning and he is roasted.

And to ensure that the Damned do not rise again and commit more sins, the punishment scenes usually decorate the last registers of the burial chambers of the royal tombs in the Valley of the Kings as parts of the different books of the afterlife, referring to their place in the deepest recess of the Underworld. 


\section{References}

i Janssen, J., (1984), 'on the ideal lifetime of the Egyptians', OMRO 31, pp. 33-44.

4Zandee, J.,(1960), Death As An Enemy, Leiden.

ii Allen, J., (1976), "The Funerary Texts of the king Wahkare Akhoty on a Middle Kingdom Coffin", in: H.Johnson, J.\&F.Wente, A., (eds.,), Studies in Honor of George R.Hughes, SAOC 39, 1-2.9

4Zandee, J.,(1960), Death As An Enemy, Leiden.

iii Hornung, E., (1990), The valley of the Kings: Horizon of Eternity, New York.

iv Erman, A. \& Grapow, H., (1929-1971), Wörterbuch der Ägyptischen Sprache I-V, Leipzig.

14Hornung, E., (1963), Das Amduat: Die Schrift des Verborgenen Raumes ,ÄA 7-I, Wiesbaden.

16Hornung, E., (1967), Das Amduat: Die Schrift Des Verborgenen Raumes, Band 13-III, Wiesbaden .

v Von Bissing, W., (1950), " Tombeaux d'époque romaine á Akhmim", ASAÉ 50, 547-576.

17Hornung, E., (1997), Die Unterweltsbücher der Ägypter, Düsseldorf.

vi Piankoff, A., (1954), The Tomb of Ramesses VI, vol.1, New York.

24 Roberson, J., (2007), The Book of the Earth: A Study of Ancient Egyptian Symbol- Systems and the Evolution of New Kingdom Cosmographic Models, thesis submitted in accordance with the requirments for the Degree of Doctor of Philosophy, University of Sylvaniaania.

17Hornung, E., (1997), Die Unterweltsbücher der Ägypter, Düsseldorf.

23Hornung, E.,(1999), The Ancient Egyptian Books of the Afterlife, New York.

vii Hournung, E., (1992), Texte Zum Amduat II, Langfassung 4 bis 8 Stunde, AH 14, Genéva.

12Erman, A. \& Grapow, H., (1929-1971), Wörterbuch der Ägyptischen Sprache I-V, Leipzig.

12Erman, A. \& Grapow, H., (1929-1971), Wörterbuch der Ägyptischen Sprache I-V, Leipzig.

14Hornung, E., (1963), Das Amduat: Die Schrift des Verborgenen Raumes, ÄA 7-I, Wiesbaden .

viii Warburton, D., (2012), Architecture, Power and Religion: Hatshepsut, Amun\&Karnak in Context, Berlin.

15Hornung, E. \& Abt, T., (2009), The Egyptian Amduat, The Book of the Hidden Chamber, Germany.

15Hornung, E. \& Abt, T., (2009), The Egyptian Amduat, The Book of the Hidden Chamber, Germany.

ix Geßler-Löhr, B., (1983), Die Heiligen Seen Ägyptischer Temple: Eine Beitrag zur Deutung Sakraler Baukunst im Alten Ägypten, HÄB 21, Hildesheim.

x De Buck, A., (1935-1961), The Ancient Egyptian Coffin Texts, 7 vols, Chicago.

xi Abd El-Sayed, M., (2017), The Scenes of Serpent Deities at the Underworld Books in Ancient Egypt, A Dissertation for the Degree of Doctor of Philosophy in Tourist Guidance, Minia.

36Abbas, E. S., (2009), The Lake of Knives and the Lake of Fire: Studies in the Topography of Passage in Ancient Egyptian Topography of Passage in Ancient Egyptian Religion Literature, BAR 2144 Oxford.

36Abbas, E. S., (2009), The Lake of Knives and the Lake of Fire: Studies in the Topography of Passage in Ancient Egyptian Topography of Passage in Ancient Egyptian Religion Literature, BAR 2144 Oxford.

xii Pippy, J., (2011), Egyptian Origin of the Book of Revelation, Canada.

xiii Hornung, E., (2013), The Egyptian Book of Gates, Zurich.

24Roberson, J., (2007), The Book of the Earth: A Study of Ancient Egyptian Symbol- Systems and the Evolution of New Kingdom Cosmographic Models, thesis submitted in accordance with the requirments for the Degree of Doctor of Philosophy, University of Sylvaniaania.

23Hornung, E.,(1999), The Ancient Egyptian Books of the Afterlife, New York.

24Roberson, J., (2007), The Book of the Earth: A Study of Ancient Egyptian Symbol- Systems and the Evolution of New Kingdom Cosmographic Models, thesis submitted in accordance with the requirments for the Degree of Doctor of Philosophy, University of Sylvaniaania.

xivDarnell, J., (2004), Enigmatic Netherworld Books of the Solar-Osirian Unity, Switzerland.

24Roberson, J., (2007), The Book of the Earth: A Study of Ancient Egyptian Symbol- Systems and the Evolution of New Kingdom Cosmographic Models, thesis submitted in accordance with the requirments for the Degree of Doctor of Philosophy, University of Sylvaniaania.

24Roberson, J., (2007), The Book of the Earth: A Study of Ancient Egyptian Symbol- Systems and the Evolution of New Kingdom Cosmographic Models, thesis submitted in accordance with the requirments for the Degree of Doctor of Philosophy, University of Sylvaniaania.

xv P (3)-n-št3y "the one belonging to the Mysterious", see: Ranke, H., (1935), Die Ägyptischen Personennamen I, New York.

24Roberson, J., (2007), The Book of the Earth: A Study of Ancient Egyptian Symbol- Systems and the Evolution of New Kingdom Cosmographic Models, thesis submitted in accordance with the requirments for the Degree of Doctor of Philosophy, University of Sylvaniaania.

xvi Manassa, C., (2007), The Late Egyptian Underworld: Sarcophagi and Related Texts from the Nectanebid Period, ÄAT, Band 72, Wiesbaden.

24Roberson, J., (2007), The Book of the Earth: A Study of Ancient Egyptian Symbol- Systems and the Evolution of New Kingdom Cosmographic Models, thesis submitted in accordance with the requirments for the Degree of Doctor of Philosophy, University of Sylvaniaania.

43 Darnell, J., (2004), Enigmatic Netherworld Books of the Solar-Osirian Unity, Switzerland.

xvii Rinter, R., (1984), "A Uterine Amulet in the Oriental Institute Collection", JNES 43, pp. 209-221.

24Roberson, J., (2007), The Book of the Earth: A Study of Ancient Egyptian Symbol- Systems and the Evolution of New Kingdom Cosmographic Models, thesis submitted in accordance with the requirments for the Degree of Doctor of Philosophy, University of Sylvaniaania.

4Zandee, J.,(1960), Death As An Enemy, Leiden.

32 Backes, B., (2005), Das Altägyptische Zweiwegebuch: Studien zu den Sargtextsprüchen 1029-1130, ÄA 69, Wiesbaden.

23 Hornung, E.,(1999), The Ancient Egyptian Books of the Afterlife, New York.

16Hornung, E., (1967), Das Amduat: Die Schrift Des Verborgenen Raumes, Band 13-III, Wiesbaden.

23Hornung, E.,(1999), The Ancient Egyptian Books of the Afterlife, New York.

xviii Hornung, E., (1994), Texte Zum Amduat III, Langfassung 9 bis 12 Stunde, AH 15, Genèva.

xix Budge, E., (2010), The Egyptian Heaven and Hell, Unites States.

xx Hornung, E., (1979), Das Buch von den Pforten des Jenseits nach den Versionen des Neuen Reiches, AH 1-7, Genéve.

49Hornung, E., (1979), Das Buch von den Pforten des Jenseits nach den Versionen des Neuen Reiches, AH 1-7, Genéve.

42 Hornung, E., (2013), The Egyptian Book of Gates, Zurich.

49Hornung, E., (1979), Das Buch von den Pforten des Jenseits nach den Versionen des Neuen Reiches, AH 1-7, Genéve.

xxi Pinch, G., (1994), Magic In Ancient Egypt, London.

xxii "Winds"; "storm"; "twisted of heart", all of them is Seth. The claim of the speaker's identity with the god Seth evokes the god's best (or only) appreciated mythical role, as defender of the sun god (Te Velde, H., (1967), Seth, God of Confusion: A Study of His Role in Egyptian Mythology and Religion, Leiden)

14 Hornung, E., (1963), Das Amduat: Die Schrift des Verborgenen Raumes, ÄA 7-I, Wiesbaden.

xxiii Kritsky, G., (2015), The Tears of Re: Beekeeping in Ancient Egypt, New York.

23 Hornung, E.,(1999), The Ancient Egyptian Books of the Afterlife, New York.

49Hornung, E., (1979), Das Buch von den Pforten des Jenseits nach den Versionen des Neuen Reiches, AH 1-7, Genéve. 